developed to make such a specialism possible (Industrial Behaviour and Personnel Management. (Industrial Relations Series.) By Prof. Tom Lupton. Pp. 59. London: Institute of Personnel Management, 1964. 7s. 6d.). If society as a whole is to reap the benefits of modern tech. nology, social structures must be adapted rapidly and appropriately to meet its demands. Prof. Lupton doubts whether the problems we are facing will yield to "the mixture of philanthropic ideology and administrative technique which are the typical basis of much personnel management at present", and he sees a completely new role for the personnel manager. His booklet should cause many readers to re-examine cherished beliefs, and many personnel managers to consider their adequacy for their existing positions.

\section{Scientific Research in Schools}

THE seventh annual report to the Council of the Royal Society of the Scientific Research in Schools Committee records that 108 science teachers are carrying out investigations with the assistance of the Committee and that the Council's grant of $£ 2,000$ has been supplemented by $£ 1,000$ from the Atomic Energy Authority for teachers wishing to pursue research of interest to the Authority (Pp. 16. London: The Royal Society, 1964). Further support has been received from 11 industrial concerns. Of the projects, 39 broadly fell into the field of biology, 37 of chemistry, 13 of physies, and 9 of geology. As an experimental extension to encourage the development of applied research in schools, a project was also supported for two school science teachers to join one of the research teams of the Proctor Department of Food and Leather Science, University of Leeds, for 4 weeks during the summer vacation. Besides details of the schools involved and the research projects, the report includes a list of publications in connexion with the projects.

\section{Choosing a Career}

The series of pamphlets issued by the Central Youth Employment Executive deserves the attention of all young people who have not decided what to do with their lives. The pamphlets cover a wide variety of possible careers, including the various branches of medical and veterinary work, various hospital services and social work, and careers in the arts, in business and in crafts ranging from plumbing to woodwork, stonemasonry and journalism. No. 1 in the series is a general booklet which discusses the points which should be considered before a choice of a career is made. No. 111, Veterinary Science, details the preliminary qualifications required for work in this field, and indicates its scope, which includes various kinds of laboratory and field work, as well as veterinary practice. The booklet (Central Youth Employment Executive. Choice of Careers, No. 111: Veterinary Science. Second edition. Pp. $28+9$ photographs. London: H.M. Stationery Office, 1964. 1s. 3d.) also gives information about the available courses of training, their cost, and their location, with the addresses to which application must be made. The booklets can be obtained from H.M.S.O. or from booksellers and their prices vary from $6 d$. to $2 s$. $6 d$.

\section{American Expedition to New Guinea}

IN 1959 the American Museum of Natural History sent an expedition to New Guinea consisting of Leonard J. Brass, leader and botanist, and H. M. Van Deusen, mammalogist. Although the sixth expedition to the Island under the Richard Archbold Foundation, it was the first to cover the north-east-that is, the trusteeship territory of New Guinea-and was based on Lae (Bulletin of the American Museum of Natural History, 127, Article 4: Results of the Archbold Expedition. No. 8o; Summary of the Sixth Archbold Expedition to New Guinea (1959). By L. J. Brass. Pp. 145-216 + plates 2-3. New York:
American Museum of Natural History, 1964. 2.50 dollars). J. D. Collins, owner of a young coffee plantation, joined them, and they were assisted by six regular employees recruited locally, some with experience of preceding expeditions. Although Brass discusses briefly his classification of vegetation types and compares it with that of Robbins, used as part of the land-use investigations begun in 1953 by the Australian Commonwealth Scientific and Industrial Research Organization, the expedition was essentially to make collections of mammals, amphibians, reptiles and insects, and of plants, for deposition in the American Museum of Natural History-consequently enriched by some 55,000 specimens. After a brief general description of the area, illustrated by 23 excellent photographs, Brass mentions previous collecting expeditions and then details the itinerary from March 22 until December 20. Extensive use was made of air reconnaissance, but there is high praise for the 'Land Rover' used to cover the main journeys. Half the report is then taken up by the description of the 14 collecting stations. In view of the intense activity of Australian scientists over the whole of the eastern half of New Guinea, it seems a little unfortunate that there was apparently little liaison, and five years seems a long time to have waited for the summary report.

Information Bulletin of the Soviet Antarctic Expedition

Prompted by Dr. G. de Q. Robin's review of Volumes 1 and 2 of the Elsevier translations of Information Bulletin of the Soviet Antarctic Expedition (Nature, 204, 110; 1964) and the pending publication of Volume 3 (the three volumes will cover Bulletins 1-30), Dr. Waldo E. Smith, executive secretary of the American Geophysical Union, has written to the Editor as follows: "It is possibly of interest to your readers to know that the American Geophysical Union is continuing this series, more or less on a serial basis . . . Nos. 31-42, inclusive, are available on subscription at a price of $\mathbf{3 6}$ dollars and will be published under six covers. The first six of these numbers have already been produced in English edition. It is one of our purposes in undertaking this series to get these on a current basis in order that they might be of maximum use to those engaged in Antarctic studies. We anticipate the other six to be available during the next few months, ending perhaps in January or February. We have plans to continue the series at least through No. 52". Further information can be obtained from Dr. Waldo E. Smith, Suite 506, 114519 th Street, N.W., Washington, D.C. 20036.

\section{Queen Elizabeth Forest Park}

The Queen Elizabeth Forest Park in Scotland was established by the Forestry Commission to commemorate Her Majesty's Coronation in 1953. The Park lies within easy reach of Edinburgh, Glasgow and much of industrial Scotland, and is on a well-known and much-frequented touring route. It includes Ben Lomond, the Trossachs, and the undulating forests of Loch Ard and Rowardennan, as well as many picturesque tree-lined lochs. Situated in its midst is the village of Aberfoyle which forms a convenient 'centre'. Within the Park are two distinct types of landscape. To the south and east lie the gently undulating valleys and fertile farmlands of the River Forth, while to the north and west lies the rugged scenery so characteristic of the Scottish Highlands. The park thus lies across the division between Highlands and Lowlands and is crossed by the Highland fault marking the geological division between the two. The Short Guide to the Queen Elizabeth Forest Park (Pp. 14+4 photographs and map. London: H.M. Stationery Office, 1964. 1s.) describes its topography, history, botany, forestry and animal life, as well as the literature associated with the Forest. Amenities include the David Marshall Lodge which was presented to the nation by the Carnegie United Kingdom Trust in 1961. 